Synthesis of Natural

Products and

Potential Drugs

\title{
Synthesis of Raltegravir
}

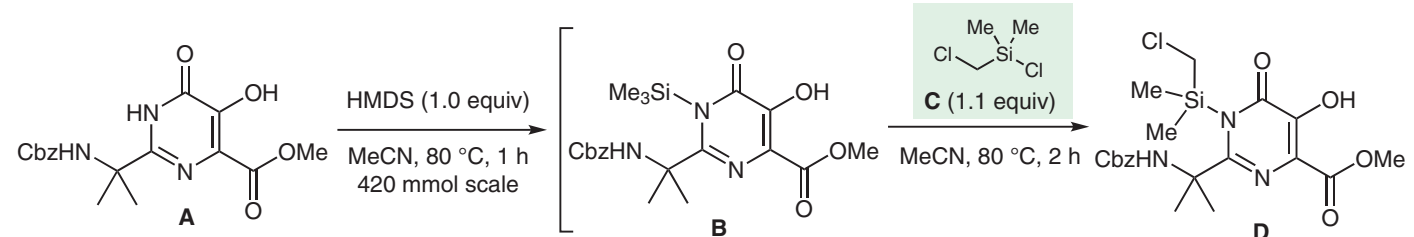

\section{Key words}

Raltegravir

HIV integrase

inhibitor

N-methylation

Chapman

rearrangement<smiles>CC(C)(NC(=O)OCc1ccccc1)c1nc(C(=O)NCC2CCCCC2)c(O)c(=O)n1C[Si](C)(C)Cl</smiles>

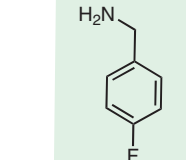

G (1.2 equiv)

$\mathrm{Et}_{3} \mathrm{~N}$ (1.2 equiv) $\mathrm{MeOH}, 65^{\circ} \mathrm{C}, 1 \mathrm{~h}$<smiles>COC(=O)c1nc(C(C)(C)NC(=O)O)n(C[Si](C)(C)Cl)c(=O)c1O</smiles>

Chapman

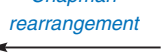

KF (1.25 equiv)

$\mathrm{MeOH}, 65^{\circ} \mathrm{C}, 1-2 \mathrm{~h}$

$82 \%$ from $A$<smiles></smiles><smiles>Cc1nnc(C(=O)Cl)o1</smiles><smiles>C=C(NC)c1nc(C(C)(C)NC(=O)c2nnc(C)o2)n(C)c(=O)c1[O-]</smiles>
$99.6 \%$ pure

$\mathrm{Me}$<smiles>[CH]1CCCC1</smiles><smiles></smiles><smiles>[B][B]</smiles>

Significance: Raltegravir potassium (Isentress ${ }^{\circledR}$ ) is an HIV integrase inhibitor manufactured by Merck \& Co. (G. R. Humphrey et al. Org. Process Res. Dev. 2011, 15, 73). A major challenge in the synthesis of raltegravir is the selective $\mathrm{N}$-methylation of the pyrimidone intermediate $\mathbf{A}$. Conventional methylating agents such as Mel produced mixtures of $\mathrm{N}$ - and $\mathrm{O}$-methylated pyrimidones that were difficult to separate.

SYNFACTS Contributors: P. J. Kocienski

Synfacts 2017, 13(12), 1227 Published online: 17.11.2017 Dol: 10.1055/s-0036-1591624; Reg-No.: K05417SF
Comment: Highly selective $\mathrm{N}$-methylation of $\mathbf{A}$ was achieved by the three-step sequence developed by workers at Pharmathen involving (1) N-alkylation of $\mathbf{B}$ with $\mathbf{C}$ to give $\mathbf{F},(2)$ amidation of $\mathbf{F}$ with amine $\mathbf{G}$, and (3) desilylation of $\mathbf{H}$ with potassium fluoride in methanol. By this procedure, the desired $\mathrm{N}$-methylpyrimidone I was obtained in $82 \%$ overall yield on a $420 \mathrm{mmol}$ scale. For a mechanism for the formation of $\mathbf{I}$, see: $\mathrm{V}$. A. Pestunovich and co-workers J. Organomet. Chem. 1989, 361, 147. 